Revista Brasileira de Meteorologia, v.26, n.2, 181 - 188, 2011

\title{
TRANSPIRATION OF IRRIGATED APPLE TREES AND CITRUS FROM A WATER POTENTIAL GRADIENT APPROACH IN THE LEAF-ATMOSPHERE SYSTEM
}

\author{
ANDRÉ BELMONT PEREIRA ${ }^{1}$, NILSON AUGUSTO VILLA NOVA², LUIZ FERNANDO PIRES ${ }^{1}$, \\ ADRIANE THEODORO ALFARO ${ }^{3}$
}

\author{
${ }^{1}$ Universidade Estadual de Ponta Grossa, Ponta Grossa, PR, Brasil \\ ${ }^{2}$ Escola Superior de Agricultura Luiz de Queiroz (ESALQ), Universidade de São Paulo, Piracicaba, SP, Brasil \\ ${ }^{3}$ Centro de Ensino Superior dos Campos Gerais (CESCAGE), Ponta Grossa, PR, Brasil
}

andre.pereira@pq.cnpq.br, navnova@esalq.usp.br, lfpires@uepg.br, adrianealfaro@cescage.edu.br

Received April 2009 - Accepted August 2010

\begin{abstract}
The uptake of water from the roots of crops comes to being a physiological response of the plant to the water loss process through its stomata. Getting to know the daily transpiration rates throughout the phenological cycle allows for the application of the ideal amount of irrigation water at the right moment to maximize production with environmental protection. Since transpiration direct measurements at the field, mainly for trees in general, are to be of operational difficulty and relatively high cost we came up with a methodology that allows one to calculate the daily transpiration rates of apple trees and citrus orchards from variables of both the physical environment and the crop. The input data of the proposed model are air temperature, air relative humidity, photoperiod duration, and leaf area. Estimated transpiration rates based on the water potential gradient between the air and leaf approach were comparable in apple trees and citrus orchards. Sap flow daily values were obtained by means of the heat balance method at Bordeaux, France, and Piracicaba, SP, Brazil. All the coefficients of determination of the regression equations obtained herein were higher than 0.93 . This allows one to calculate the amount of irrigation water to be applied throughout the crop growing seasons with a high precision as a function of meteorological data and crop covering density at the sites in the study. Keywords: modeling, water consumption, chemical potential, diffusive resistance, woody crops, weather, meteorological data, irrigation planning.
\end{abstract}

RESUMO: TRANSPIRAÇÃO DE MACIEIRAS E CITROS IRRIGADOS A PARTIR DO GRADIENTE DE POTENCIAL ÁGUA NO SISTEMA FOLHA-ATMOSFERA

A tomada de água pelas raízes de espécies vegetais cultivadas vem a ser uma resposta fisiológica da planta ao processo de perda de água através de seus estômatos. Conhecer a transpiração possibilita a determinação da quantidade ideal de água a ser aplicada no momento certo com vistas à maximização da produção com proteção ambiental. Como a medida direta da transpiração no campo, principalmente em árvores, constitui procedimento que envolve dificuldade operacional e custo relativamente elevado, propôs-se neste estudo uma metodologia de cálculo da transpiração diária de macieiras e citros a partir de variáveis do meio físico e da planta. As variáveis de entrada do modelo proposto compreendem a temperatura do ar, a umidade relativa do ar, a duração do fotoperíodo e a área foliar da árvore. Taxas de transpiração estimadas com base no gradiente de potencial da água entre o ar atmosférico e a câmara estomática das folhas foram comparadas com valores diários de fluxo de seiva de macieiras e citros determinados através do método de balanço de calor nas regiões de Bordeaux, sudoeste da França, e de Piracicaba, SP, Brasil. O método apresentou estimativas altamente comparáveis às medidas de fluxo de seiva em pomares de macieiras e citros irrigados por gotejamento, visto que os coeficientes de determinação das equações de regressão obtidas foram superiores a 0,93 , podendo-se inferir que 
a lâmina de irrigação a ser adotada durante o ciclo de desenvolvimento dessas espécies frutíferas pode ser estimada com elevada precisão a partir do conhecimento do regime vigente de elementos meteorológicos e da densidade de cobertura vegetal.

Palavras-chave: consumo hídrico, resistência estomática, macieiras, citros, tempo meteorológico.

\section{INTRODUCTION}

The transpiration of crops is a variable depending on the climate, soil and plant with direct measurements at the field of operational difficulty, mainly for trees in general. Valancogne and Nasr (1993) showed that when apple trees of a small height do not experience water deficiency in the soil, the sap flow determined by the heat balance method might depict very well the daily transpiration rates. Besides the great validity of the methods based on the supply of heat to the branches of trees such methods feature certain restrictions under uneventful usage in orchards of wood crop species. For practical applications the utilization of estimation methods of transpiration rates that take into account meteorological elements and crop parameters, such as leaf area or leaf area index, is considerably desirable in scientific studies.

The Penman-Monteith equation has been adapted for the calculation of transpiration from leaves and is generally used for the estimation of apple trees transpiration rates. The application of such equation requires not only meteorological data collected at the ambient of the crop in study (net radiation at the dossel level, air temperature and water vapor saturation deficit, wind speed) but also assessment of crop variables, such as conductance to diffusion of water vapor through the stomata and aerodynamic conductance, which are difficult to determine (Villa Nova et al., 2002).

The heat balance has been widely utilized in studies that deal with water relationships of woody crop species, such as apple trees (ValancoFne and Nasr, 1993; Weibel and de Vos, 1994; Angelocci, 1996), peach trees (Shackel et al., 1992), pecan trees (Steinberg et al., 1990), coffee trees (Gutiérrez et al., 1994; Marin, 2003), grape (Braun and Schmid, 1999) and young plants of citrus (Trejo-Chandria et al., 1997; Marin et al., 2003; Coelho Filho et al., 2005). The literature reports that the outcomes from the heat balance approach are usually comparable to those obtained with weight lysimeters, since the lysimetry itself constitutes a precise technique for determining evapotranspiration and transpiration of cultivated species. Coelho Filho et al. (2005) reported that the measurements of transpiration rates obtained by both evaluation methods of water consumption throughout a span varying from 30 minutes to 24 hours have indicated differences lower than $10 \%$. Transpiration rates determined by the heat balance method can also be comparable to measurements obtained by dynamic equilibrium porometers. According to Angelocci (2001), the porometric measurements present two basic problems: a) one related to the environmental condition because during the measurement procedure, the sampled leaf remains within the porometer chamber and is exposed to conditions that differ from those of its natural environment, especially concerning the wind speed; b) other, evidences that a high spatial variability of porometric measurements are a result of the heterogeneity of stomata conductance at certain spots on an isolated leaf.

Important advances in several fields of agronomical research have been achieved related to quantifying the water consumption of isolated trees at variable temporal scales by means of the heating technique of a segment of branch or stem provided by a heat source. Morpho-physiological characteristics of the crop in study, environmental conditions not related to its proper operation and care during the installation of the sensors are currently well known and allow one to obtain reliable data. While the heat balance approach is of some benefit in research and development; it still seems to be inadequate for usage on a large scale because of the difficulties involving practical and operational aspects, analysis and data processing being the main obstacles for its generalized application (Marin et al., 2008).

Thus, we propose a new methodology for the calculation of daily transpiration rates of apple trees and citrus orchards from the following meteorological elements and crop parameters: mean air relative humidity, mean air temperature, photoperiod duration, and leaf area of the tree. The proposed approach dismisses the utilization of the conductance to diffusion of water vapor, aerodynamic conductance and net radiation at the dossel level and is the basis for the existing differences between water potential in the atmospheric air and within the stomachic chamber of the leaves. Such a gradient is the driving-force of the transpiration process. Its utilization as a tool for the maximization of yields with a better reclamation of the water resources under drip irrigation system in orchards was tested as to its viability, taking into consideration the data of sap flow collected by Angelocci (1996) in apple trees, as well as by Marin (2000) in citrus orchards under distinct climatic conditions.

\section{MATERIAL AND METHODS}

\subsection{Conception of the proposed methodology}

By taking into account that the water vapor potential in the atmosphere ( $\Psi)$ might be defined in compliance with the equation proposed by Villa Nova et al. (1996): 


$$
\Psi=4.55 * T^{*} \operatorname{Ln}\left(\frac{R H}{100}\right)
$$

where: $\mathrm{T}=$ absolute air temperature (Kelvin); $\mathrm{RH}=$ air relative humidity (\%).

Equation 1 defines the value of potential energy of the water vapor per unit of volume of atmospheric air. Considering that $1 \mathrm{~atm}=98.1 \mathrm{Joule}^{\mathrm{meter}}{ }^{-3}$ of wet air and substituting such unit conversion factor for (1), we will have:

$$
\Delta \Psi=446 * T * \operatorname{Ln}\left(\frac{R H}{100}\right)
$$

In Equation $2 \Delta \Psi$ expresses the value of Gibbs free energy per unit of volume of atmospheric air available to stomachic transpiration. Supposing that the dossel of the crop has a stomachic resistance $\mathrm{Rs}\left(\mathrm{s} \mathrm{m}^{-1}\right)$ and taking into consideration the latent heat for water evaporation corresponding to $2.45 \times 10^{6}$ Joule liter ${ }^{-1}$, the daily transpiration rate calculated in liters per tree per day (TC) will be defined by:

$$
T C=\frac{446^{*} T * \operatorname{Ln}\left(\frac{R H}{100}\right) * N * 3600 * L A}{R S * 2.45 * 10^{6}}
$$

Or simplifying,

$$
T C=-\frac{0.655 * T * \cdot \operatorname{Ln}\left(\frac{R H}{100}\right) * N * L A}{R s}
$$

where: LA is the leaf area of the tree in squared meter per plant, $\mathrm{N}$ is the photoperiod duration in hours, and 3600 is the conversion factor of $\mathrm{N}$ in seconds.

\subsection{Experimental data}

Transpiration rates were measured by means of the heat balance approach for both crop species considered in the current study. For citrus, the experimental data was collected by Marin (2000) in irrigated orchards with foliar surfaces of 99 and 48 $\mathrm{m}^{2}$, under a spacing of $8.0 \times 5.0 \mathrm{~m}$ with sowing performed at the beginning of January (rainy season) throughout the year of 1999 in Piracicaba, SP, Brazil. For apple trees, the experimental data with regard to the measured transpiration rates was collected by Angelocci (1996) in southern France for different growing seasons of the years 1988 and 1989 in irrigated orchards with leaf areas of $4.7 ; 7.8 ; 9.3 ; 11.3 ; 15.7$ and $20.6 \mathrm{~m}^{2}$.
Leaf area (LA) was measured by means of a LICOR leaf area measurer, model 320-SE, for both crop species at the aforementioned localities.

An automatic weather station from Campbell Scientific Inc., along with a CR1000 datalogger and accessories, model INST-PACK, was installed at the citrus and apple tree orchards aiming at the monitoring of all meteorological elements throughout the crop growing seasons of particular interest at the regions in study. Daily mean air temperature $\left({ }^{\circ} \mathrm{C}\right)$ and relative humidity (\%) were measured by sensors based on the electric thermal effect (sensors of temperature and relative humidity Vaisala with a 10-plate meteorological shelter, model HMP45CL12-GM). The photoperiod duration (N), in hours, the semi-arc from the meridian crossing to the sunset $(\mathrm{H})$, in degrees, and the solar declination, in degrees, were calculated by the expression employed by Pereira et al. (2003).

The crop resistance (Rs, in s $\mathrm{m}^{-1}$ ) was obtained by Equation 4, isolating Rs and substituting TC (liters tree ${ }^{-1} \mathrm{day}^{-1}$ ) for measured transpiration values of citrus and apple trees(TM, in liters $\operatorname{tree}^{-1} \mathrm{day}^{-1}$ ).

\subsection{Statistical analysis}

The relationship between calculated values of Rs for both citrus and apple trees under local climatic conditions and measured values of RH has been attained herein for the proposition of the regression model faced with a simple regression study. Thus Rs presented in Equation 4 was substituted for the mathematical function that sets up a relationship between the diffusive resistance of the stomata to the water loss process and the saturation degree of the atmospheric air. The validation of the methodology in study has been assessed by means of a comparison between measured and calculated transpiration rates, taking into account an independent series of data. The accuracy of the estimation equations obtained was expressed by the coefficient of determination $\left(R^{2}\right)$ (Legates and McCabe, 1999). Its exactness might be observed by the dispersion of the data around the fitted line of the estimates in a 1:1 graphic, which was quantified through the agreement index (d) proposed by Willmott et al. (1985), once the values of coefficients of correlation and determination analyzed separately can lead to interpretations not always suitable for the performance of the studied model.

In this paper, a new index $c$ proposed by Camargo and Sentelhas (1995) was also adopted to indicate the performance of the model, putting together the accuracy $R$ and exactness $d$ indices, being defined by the multiplication between both indices.

In order to evaluate the error of estimates two statistical parameters were calculated, such as the mean absolute percentage error (MAPE) and smoothed absolute percentage error (SAPE), as described by Goodwin and Lawton (1999). 


\section{RESULTS AND DISCUSSION}

The results of transpiration rates of apple trees (Angelocci, 1996) for five trees with different leaf areas throughout the crop growing season of 1988, as well as for four trees with different leaf areas in 1989 are shown in Tables 1 and 2 , respectively. Daily mean data of air temperature $\left(\mathrm{T},{ }^{\circ} \mathrm{C}\right)$ and air saturation deficit $(\Delta \mathrm{e}, \mathrm{kPa})$ for some days of the selected years (DJ) were also reported.

\subsection{Estimation of the values of stomachic resistance of apple trees}

The estimates of the stomachic resistance of apple tree leaves were obtained from the Equation 4, according to 12 dates selected from the years 1988 and 1989, as a function of the available data set collected at the studied site. Daily data of air saturation pressure deficit $(\Delta \mathrm{e}, \mathrm{kPa})$, mean air absolute temperature (T, Kelvin), mean relative humidity (RH, \%), day length or photoperiod duration ( $\mathrm{N}$, hours), transpiration rate measured by the heat balance approach (TM, L tree ${ }^{-1}$ day $\left.^{-1}\right)$, leaf area $\left(\mathrm{LA}, \mathrm{m}^{2}\right)$ and dossel stomachic resistance (Rs, $\left.\mathrm{s} \mathrm{m}^{-1}\right)$ are presented in Table 3 for the considered dates.

It is recognized that Rs is highly dependent on the atmospheric demand, which is a function of the relative humidity

Table 1 - Meteorological data and transpiration rates measured (TM, L tree $\mathrm{day}^{-1}$ ) by the heat balance method in apple tree orchards at Bordeaux, southwestern France, throughout the crop growing season of 1988.

\begin{tabular}{|c|c|c|c|c|c|c|c|}
\hline \multirow{3}{*}{ DJ } & \multicolumn{2}{|c|}{$\begin{array}{c}\text { Meteorological } \\
\text { data }\end{array}$} & \multirow{2}{*}{$\begin{array}{c}\text { Tree } 1 \\
\mathbf{L A}=\mathbf{9 . 3} \mathbf{~ m}^{2}\end{array}$} & \multirow{2}{*}{$\begin{array}{c}\text { Tree } 2 \\
\mathrm{LA}=11.3 \mathrm{~m}^{2}\end{array}$} & \multirow{2}{*}{$\begin{array}{c}\text { Tree } 3 \\
\mathrm{LA}=4.7 \mathrm{~m}^{2}\end{array}$} & \multirow{2}{*}{$\begin{array}{c}\text { Tree } 4 \\
\text { LA }=7.5 \mathrm{~m}^{2}\end{array}$} & \multirow{2}{*}{$\begin{array}{c}\text { Tree } 5 \\
\mathbf{L A}=8.1 \mathrm{~m}^{2}\end{array}$} \\
\hline & $\mathbf{T}$ & $\Delta \mathrm{e}$ & & & & & \\
\hline & $(\mathrm{C})$ & $(\mathbf{k P a})$ & TM & TM & TM & TM & TM \\
\hline 184 & 16.8 & 0.15 & 7.3 & 8.9 & 3.7 & 5.9 & 6.4 \\
\hline 188 & 19.3 & 0.56 & 15.1 & 18.3 & 7.6 & $1 ., 2$ & 13.2 \\
\hline 191 & 19.5 & $0, .64$ & 15.3 & 18.6 & 7.7 & 12.3 & - \\
\hline 192 & 21.3 & 0.83 & 17.8 & 21.7 & 9.0 & 14.4 & - \\
\hline 198 & 17.6 & 0.54 & 12.8 & 15.6 & 6.5 & 10.4 & 11.2 \\
\hline 199 & 19.1 & 0.70 & 16.0 & 19.5 & 8.1 & 12.9 & 14.0 \\
\hline 200 & 20.5 & 0.75 & 16.6 & 20.2 & 8.4 & 13.4 & 14.5 \\
\hline 201 & 21.9 & 0.78 & 12.8 & 15.5 & 6.5 & 10.3 & 11.1 \\
\hline 203 & 22.2 & 0.54 & 14.0 & 17.1 & 7.1 & 11.3 & 12.2 \\
\hline 205 & 23.4 & 0.50 & 10.9 & 13.2 & 5.5 & 8.8 & 9.5 \\
\hline 206 & 19.1 & 0.62 & 15.0 & 18.2 & 7.6 & 12.1 & 13.0 \\
\hline
\end{tabular}

DJ is the number of days computed since the first of January up to the completion date.

Table 2 - Meteorological data and transpiration rates measured (TM, L tree ${ }^{-1}$ day $\left.^{-1}\right)$ by the heat balance method in apple tree orchards at Bordeaux, southwestern France, throughout the crop growing season of 1989.

\begin{tabular}{|c|c|c|c|c|c|c|}
\hline \multirow{3}{*}{ DJ } & \multicolumn{2}{|c|}{ Meteorological data } & Tree 1 & Tree 2 & Tree 3 & Tree 4 \\
\hline & $\mathbf{T}$ & $\Delta \mathbf{e}$ & LA $=20.6 \mathrm{~m}^{2}$ & $\mathbf{L A}=15.7 \mathrm{~m}^{2}$ & $\mathrm{LA}=4.7 \mathrm{~m}^{2}$ & $\mathrm{LA}=7.5 \mathrm{~m}^{2}$ \\
\hline & $\left({ }^{\circ} \mathrm{C}\right)$ & $(\mathbf{k P a})$ & TM & TM & TM & TM \\
\hline 182 & 20.7 & 0.65 & 36.9 & 28.1 & 14.0 & 8.6 \\
\hline 184 & 19.7 & 1.01 & 54.1 & 41.2 & 20.5 & 12.6 \\
\hline 185 & 22.5 & 1.41 & 57.6 & 43.9 & 21.8 & 13.4 \\
\hline 187 & 21.8 & 0.58 & 32.8 & 25.0 & 12.4 & 7.6 \\
\hline 190 & 19.4 & 0.29 & 15.4 & - & 5.8 & 3.6 \\
\hline 191 & 20.6 & 0.51 & 29.4 & 22.4 & 11.1 & 6.8 \\
\hline 192 & 20.5 & 0.74 & 38.9 & 29.7 & 14.7 & 9.1 \\
\hline 193 & 21.6 & 1.05 & 47.5 & 36.2 & 18.0 & 11.1 \\
\hline 194 & 21.9 & 1.15 & 51.8 & 39.5 & 19.6 & 12.1 \\
\hline 195 & 20.8 & 0.73 & 35.9 & 27.4 & 13.6 & 8.4 \\
\hline 197 & 23.9 & 1.88 & 59.7 & 45.5 & 22.6 & 13.9 \\
\hline
\end{tabular}

DJ is the number of days computed since the first of January up to the completion date. 
(RH). Thus the drier the air is the greater the resistance offered by the stomata to the water vapor diffusion into the atmosphere will be (Figure 1). The relationship between the Rs and RH might be expressed by the following simple linear regression, associated with a coefficient of determination of 0.96 .

$$
R v=1230.6-9.636 * R H
$$

\subsection{Estimation of the values of stomachic resistance of citrus}

The results of citrus transpiration rates measured by the heat balance method for each day of the selected years (TM, L.tree ${ }^{-1}$.day ${ }^{-1}$ ) by Marin et al. (2003), daily mean air temperature, photoperiod duration, daily mean relative humidity, leaf area of the trees and stomachic resistance (Rs, $\left.\mathrm{s} \mathrm{m}^{-1}\right)$ are shown in Table 4.

The values of Rs were obtained from Equation 4 for the selected periods, taking into consideration a range of daily

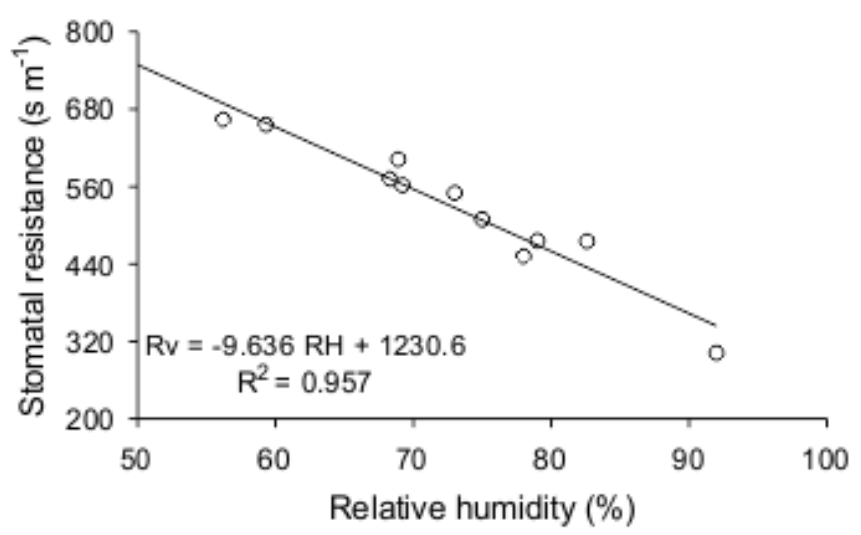

Figure 1 - Relationship between resistance to the diffusion of water vapor through the stomata and relative humidity in apple tree orchards located in Bordeaux, southwestern France. mean $\mathrm{RH}$ varying from 62 to $96 \%$, as well as the daily mean values of $\mathrm{T}, \mathrm{N}, \mathrm{LA}$ and measured transpiration rates for the corresponding dates.

As it was expected, low values of $\mathrm{RH}$ increase the gradient value of $\Psi$ between the atmosphere and the stomachic chamber of the leaves $(\Delta \Psi)$. As the theory demonstrates, high evaporative demands of the atmosphere determine a greater stomachic control of the leaves. The analysis on the relationship between the stomachic resistance of citrus and relative humidity revealed a strong correlation degree between both variables for the studied climatic site (Figure 2). The regression equation obtained was the polynomial kind, which showed a high precision given by a coefficient of determination of 0.996 .

$$
R v=0.563 *(R H)^{2}-117.57 *(R H)+6284.2
$$

\subsection{Estimation equations of transpiration rates of apple trees and citrus}

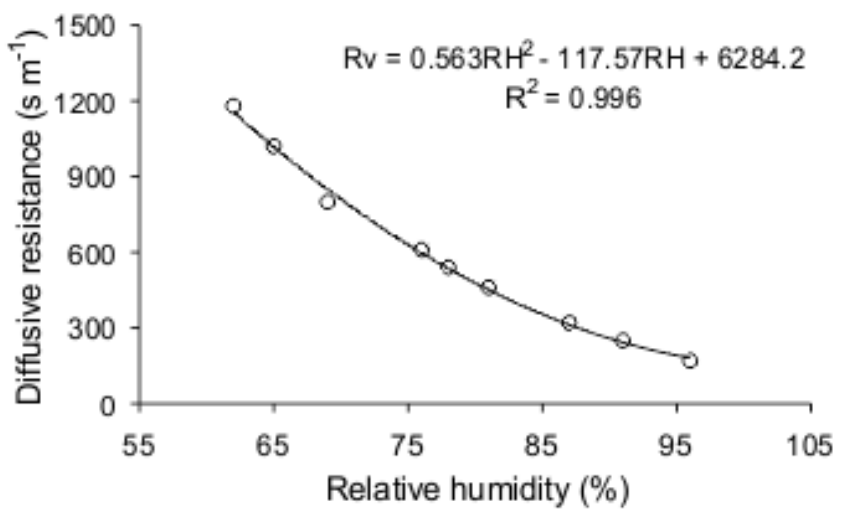

Figure 2 - Relationship between resistance to the diffusion of water vapor through the stomata and relative humidity in citrus orchards located in Piracicaba, SP, Brazil.

Table 3 - Meteorological elements and crop parameters employed on the calculation of stomachic resistance ( $\mathrm{s} \mathrm{m}^{-1}$ ) for twelve selected dates (DJ) throughout the years of 1988 and 1989. Experimental data collected at the southwestern France by Angelocci (1996).

\begin{tabular}{|c|c|c|c|c|c|c|}
\hline $\mathbf{D J}$ & $\begin{array}{c}\mathbf{T} \\
(\mathbf{K})\end{array}$ & $\begin{array}{c}\mathbf{N} \\
(\mathbf{h o u r s})\end{array}$ & $\begin{array}{c}\mathbf{R H} \\
(\boldsymbol{\%})\end{array}$ & $\begin{array}{c}\mathbf{L A} \\
\left(\mathbf{m}^{\mathbf{2}}\right)\end{array}$ & $\begin{array}{c}\mathbf{T M} \\
\left(\mathbf{L} \mathbf{t r e e}^{-\mathbf{1}} \mathbf{d}^{-\mathbf{1}}\right)\end{array}$ & $\begin{array}{c}\mathbf{R v} \\
\left(\mathbf{s ~ m}^{\mathbf{- 1}} \mathbf{)}\right.\end{array}$ \\
\hline 184 & 289.8 & 15 & 92.0 & 9.3 & 7.3 & 302 \\
\hline 188 & 292.3 & 15 & 75.0 & 9.3 & 15.1 & 509 \\
\hline 191 & 292.5 & 15 & 73.0 & 9.3 & 15.3 & 550 \\
\hline 198 & 292.1 & 15 & 68.3 & 9.3 & 12.8 & 572 \\
\hline 200 & 293.5 & 15 & 68.9 & 9.3 & 16.6 & 602 \\
\hline 205 & 296.4 & 15 & 82.6 & 9.3 & 10.9 & 475 \\
\hline 185 & 295.5 & 15 & 48.0 & 20.6 & 57.6 & 761 \\
\hline 187 & 294.8 & 15 & 78.0 & 20.6 & 31.7 & 542 \\
\hline 191 & 293.6 & 15 & 79.0 & 20.6 & 29.4 & 476 \\
\hline 192 & 293.5 & 15 & 69.2 & 20.6 & 38.9 & 562 \\
\hline 193 & 294.6 & 15 & 59.3 & 20.6 & 47.5 & 656 \\
\hline 194 & 294.9 & 15 & 56.2 & 20.6 & 51.8 & 664 \\
\hline
\end{tabular}


Table 4 - Meteorological elements and crop parameters employed on the calculation of resistance to the diffusion of water vapor in citrus orchards for nine selected dates in 1999. Experimental data collected by MARIN (2000) at Piracicaba, SP, Brazil.

\begin{tabular}{|c|c|c|c|c|c|c|}
\hline DJ & $\begin{array}{c}\mathbf{T} \\
(\mathbf{K})\end{array}$ & $\begin{array}{c}\mathbf{N} \\
(\mathbf{h o u r s})\end{array}$ & $\begin{array}{c}\mathbf{R H} \\
(\mathbf{\%})\end{array}$ & $\begin{array}{c}\mathbf{L A} \\
\left(\mathbf{m}^{\mathbf{2}}\right)\end{array}$ & $\begin{array}{c}\mathbf{T M} \\
\left(\mathbf{L}_{\mathbf{t r e e}}^{-\mathbf{1}} \mathbf{d}^{\mathbf{1}} \mathbf{)}\right.\end{array}$ & $\begin{array}{c}\mathbf{R v} \\
\left(\mathbf{s ~ m}^{\mathbf{- 1}}\right)\end{array}$ \\
\hline 15 & 298.7 & 13.27 & 91 & 99 & 91 & 250 \\
\hline 16 & 299.5 & 13.26 & 87 & 99 & 112 & 320 \\
\hline 19 & 300.6 & 13.22 & 81 & 99 & 118 & 460 \\
\hline 20 & 299.2 & 13.19 & 76 & 99 & 121 & 610 \\
\hline 22 & 298.2 & 13.18 & 62 & 99 & 101 & 1180 \\
\hline 23 & 297.8 & 13.16 & 65 & 99 & 105 & 1040 \\
\hline 28 & 297.2 & 13.09 & 69 & 99 & 107 & 870 \\
\hline 31 & 298.4 & 13.02 & 77 & 99 & 122 & 580 \\
\hline 32 & 293.5 & 13.00 & 96 & 99 & 29 & 170 \\
\hline
\end{tabular}

From Equations 4 and 5 we formulated the equation on a daily basis for determination of the calculated transpiration of apple trees (TC), which has the following predictor variables: mean relative humidity, mean air temperature, photoperiod duration and leaf area of the tree. Thus, we have:

$$
T C=\frac{0.655^{*} T * \operatorname{Ln}\left(\frac{R H}{100}\right) * N^{*} L A}{1230.6-9.636 * R H}
$$

Rearranging Equations 4 and 6 we calculated the transpiration rates of citrus plants by means of the following expression:

$$
T C=\frac{0.655 * T * \operatorname{Ln}\left(\frac{R H}{100}\right) * N^{*} L A}{0.563 *(R H)^{2}-117.57 *(R H)+6284.2}
$$

Correlation studies between the transpiration rates of citrus plants, measured by the heat balance approach and

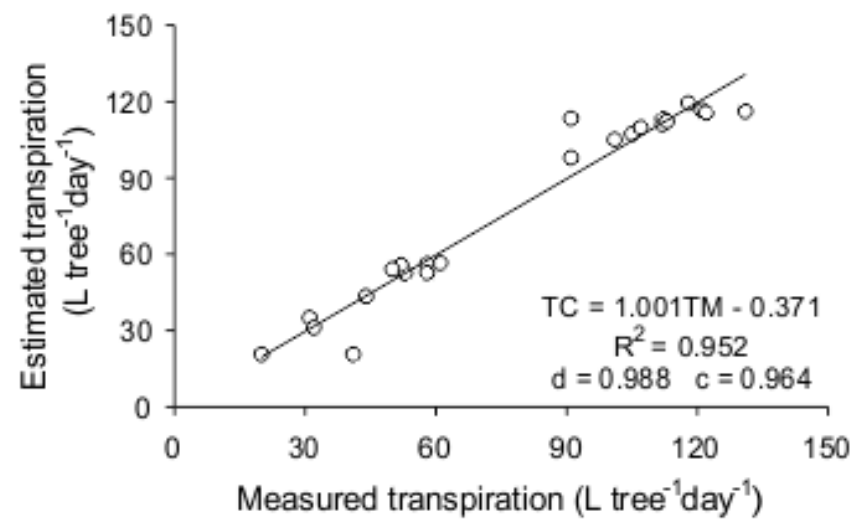

Figure 3 - Comparison between transpiration of citrus plants measured by the heat balance approach and transpiration calculated by the proposed methodology at Piracicaba, SP, Brazil, considering an independent data series. estimated by the proposed methodology (Figure3), demonstrated a strong relationship between both variables of the regression model.

The relationship between the transpiration calculated by the methodology in study (TC) and measured by the heat balance method (TM) throughout two crop growing seasons in France is shown in Figure 4. Such relationships reveal the high precision of the model proposed for the purpose of localized irrigation planning in apple tree orchards.

The coefficients $\mathrm{R}^{2}$ and $\mathrm{r}$ indicate the degree of accuracy of a particular model; however do not reveal the true exactness of the model (Pereira et al., 2003; Pereira and Villa Nova, 2008). The agreement index (d) greater than 0.95 indicated a high exactness, being in consonance with the $\mathrm{d}$ values found by Pereira et al. (2003) and Legates and McCabe (1999), as well as above the acceptable lower limit of 0.75 as recommended by Robinson and Hubbard (1990). The index c has assumed the values of $0.96,0.92$ and 0.98 for the sites and crops reported in Figures 3 and 4 , showing an excellent performance, according to the interpretation criterion of the performance models presented by Camargo and Sentelhas (1995). It is possible to verify that both accuracy, given by the trend line and the exactness demonstrated by the dispersion of the data around the fitted line of the estimates were satisfactory.

The values obtained for citrus concerning the error of estimates expressed by the MAPE and SAPE were of 7.4 and $8.0 \%$, respectively, confirming the viability of the method proposed to estimate the transpiration rates in citrus orchards at the studied site by means of the Equation 8. MAPE and SAPE values for apple trees throughout the growing season of 1989 were similar to those obtained for citrus ( 8.3 and 8.3\%, respectively) and a bit higher for the year of 1988 with values corresponding to 13.1 and $12.0 \%$, respectively. Such statistical parameters reinforce the feasibility of the proposed method for the crop and location illustrated in Figure 4.

With the advent of charging for water utilization and with the increase of the relation demand/offer, faced with the 

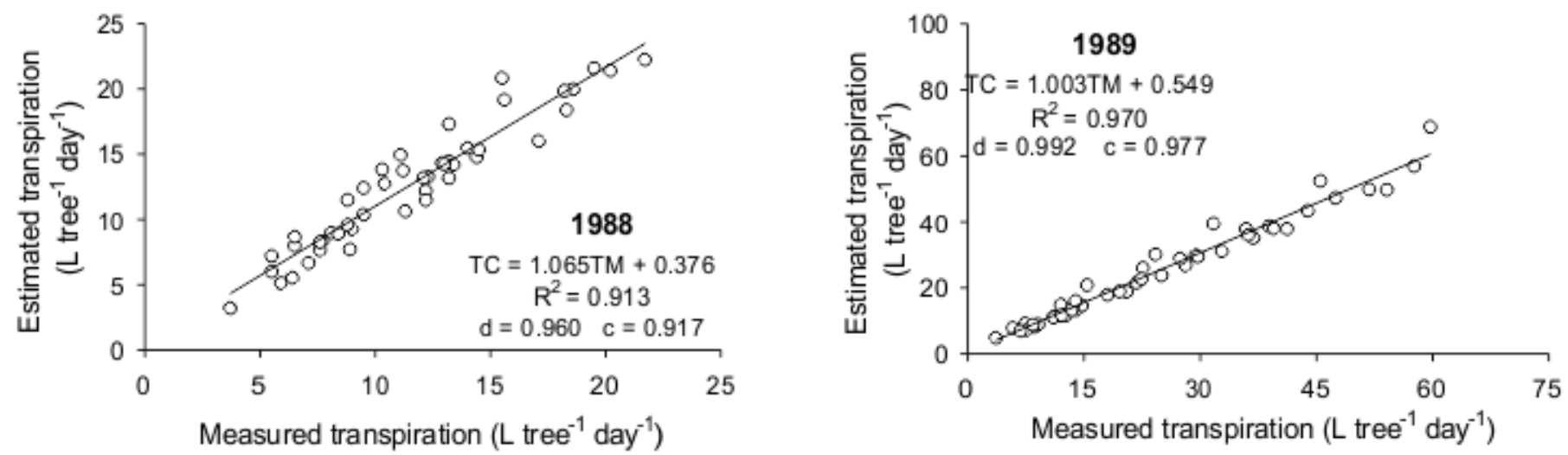

Figure 4 - Comparison between transpiration of apple trees measured by the heat balance approach and transpiration calculated by the proposed methodology at Bordeaux, France, throughout the growing seasons of 1988 and 1989, considering an independent data series.

increment of this irrigation practice at large areas of the National Territory, the localized irrigation system has been becoming more and more important in the development of irrigated agriculture. Under a condition of 178 trees per hectare grown with a spacing of $7 \times 8 \mathrm{~m}$, citrus tree, cultivar Tahiti, with an area leaf of $90 \mathrm{~m}^{2}$, requires an amount of water around 100 liters per day (Marin, 2000; Marin et al., 2003). Thus, for one hectare of citrus orchard we would have a water consumption

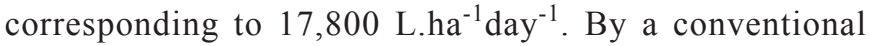
sprinkling irrigation system a usual water amount of 5 mm.day ${ }^{-1}$ would result in a water consumption of 50,000 liters per day, corresponding to about 2.8 times more in relation to the demand of localized irrigation systems.

Faced with the outcomes obtained herein, the proposed methodology developed for quantifying the water requirements of the studied woody crops has shown to be rather feasible concerning its utilization. However, further field trials must be carried out to consolidate the methodology in study under other local climatic conditions and agronomic crops.

The application of the methodology is straightforward and can be seen as a great contribution for the calculation of localized irrigation of citrus and apple tree orchards. This allows for significant water savings, which is more and more necessary, given the increasing demand on such natural resources in Brazilian Fruit Crop Science. However, it is appropriate to stand out that the aforementioned methodology needs a local calibration so that it might be employed under climatic conditions and crops quite different from those assessed in the current study.

\section{CONCLUSIONS}

It is possible to estimate with a good reliability the daily sap flow or transpiration rates of citrus plants and apple trees as a function of mean air temperature, air relative humidity, photoperiod duration, air saturation deficit and leaf area under irrigation regimes.

The proposed methodology needs to be calibrated, taking into consideration initial measurements of daily sap flow from trees with different sizes of other woody crop species under several local climatic conditions.

\section{ACKNOWLEDGMENTS}

The authors are very thankful to the Conselho Nacional de Desenvolvimento Científico e Tecnológico (CNPq) for the concession of the grants and fellowship of productivity in research, which provided the necessary support for the idealization and accomplishment of the current study. Special thanks are also devoted to Sandra Shelton, from San Francisco, California, USA, for the English review of this contribution.

\section{REFERENCES}

ANGELOCCI, L.R. Estimativa da transpiração máxima de macieiras (Malus spp.) em pomares pelo modelo de Penman-Monteith. 1996. 103 p. Tese (Livre-Docência). Escola Superior de Agricultura "Luiz de Queiroz", Universidade de São Paulo. Piracicaba. 1996.

ANGELOCCI, L.R. Métodos e técnicas de estudo das relações água-planta-atmosfera. Piracicaba: USP, ESALQ, Departamento de Ciências Exatas, 2001, 104p.

BRAUN, P.; SCHMID, J. Sap flow measurements in grapevines (Vitis vinifera L.). 1 - Stem morphology and use of the heat balance method. Plant and Soil, Dordrecht, v.215, p.39-45, 1999.

CAMARGO, A.P., SENTELHAS, P.C. Avaliação de modelos de estimativa da evapotranspiração potencial mensal em base diária para Campinas e Ribeirão Preto, SP. In: Congresso 
Brasileiro de Agrometeorologia, 7, 1995. Anais... Campina Grande: SBA, 1995. p.415-417.

COELHO FILHO, M.A.; ANGELOCCI, L.R.; CAMPECHE, L.F.S.M.; FOLEGATTI, M.V.; BERNARDES, M.S. Field determination of young acid lime plants transpiration by the stem heat balance method. Scientia Agricola, Piracicaba, v.62, n.3, p.240-247, 2005.

GOODWIN, P.; LAWTON, R. On the asymmetry of the symmetric MAPE. International Journal of Forecasting, Oxford, v.15, n.4, p.405-408, 1999.

GUTIÉRREZ, M.V.; HARRINGTON, R.; MEINZER, F.C.; FOWNES, J.H. The effect of environmentally induced stem temperature gradients on transpiration estimates from the heat balance method in two tropical woody species. Tree Physiology, Victoria, v.14, p.179-190, 1994.

LEGATES, D.R., McCABE JR., G.J. Evaluating the use of "goodness-of-fit" measures in hydrologic and hydroclimatic model validation. Water Resources Research, Amsterdam, v.35, n.1, p.233-241, 1999

MARIN, F.R. Evapotranspiração, transpiração e balanço de energia em pomar de lima ácida "Tahiti". Piracicaba, 2000. 74p. Dissertação (Mestrado em Agronomia). Escola Superior de Agricultura "Luiz de Queiroz", Universidade de São Paulo, 2000.

MARIN, F.R. Evapotranspiração e transpiração máxima em cafezal adensado. Piracicaba, 2003. 118p. Tese (Doutorado em Agronomia). Escola Superior de Agricultura "Luiz de Queiroz", Universidade de São Paulo, 2003.

MARIN, F.R.; ANGELOCCI, L.R.; VILLA NOVA, N.A. Estimativa da transpiração máxima de lima ácida, cv. Tahiti, pelo modelo de Penman-Monteith. Revista Brasileira de Agrometeorologia, Santa Maria, v. 11, n. 2, p. 237-243, 2003.

MARIN, F.R.; RIBEIRO, R.V.; ANGELOCCI, L.R.; RIGHI, E.Z. Fluxo de seiva pelo método do balanço de calor: base teórica, qualidade das medidas e aspectos práticos. Bragantia, Campinas, v.67, n.1, p.1-14, 2008.

PEREIRA, A.B., VILLA NOVA, N.A., GALVANI E. Estimation of global solar radiation flux density in Brazil as a function of a single measurement at solar noon. Biosystems Engineering, Edinburg, v.86, n.1, p.27-34, 2003.

PEREIRA, A.B., VILLA NOVA, N.A. Potato maximum yield as affected by crop parameters and climatic factors in Brazil. HortScience, North Carolina, v.43, n.5, p.1611-1614, 2008.
ROBINSON, J.M, HUBBARD, K.G. Soil water assessment model for several crops in high plains. Agronomy Journal, Madison, v.82, n.4, p.1141-1148, 1990.

SHACKEL, K.A.; JOHNSON, R.S.; MEDAWAR, C.K.; PHENE, C.J. Substantial errors in estimates of sap flow using the heat balance technique on woody stems under field conditions. Journal of the American Society for Horticultural Science, Alexandria, v.117, p.351-356, 1992. STEINBERG, S.L.; McFARLAND, M.J.; WORTHINGTON, J.W. Comparison of truck and branch sap flow with canopy transpiration in pecan. Journal Experimental Botany, Oxford, v.41, p.653-659, 1990.

TREJO-CHANDRIA, J.E.; ANGELOCCI, L.R.; OLIVEIRA, R.F. Aplicação do método de balanço de calor na determinação da transpiração de mudas de limoeiro. Scientia Agricola, Piracicaba, v.54, p.221-231, 1997.

VALANCOGNE, C.; NASR, Z. A heat balance method for measuring sap flow in small trees. In: BORGUETTI, M.; GRACE, J.; RASHI, A. (Ed.). Water transport in plants under climatic stress. Cambridge: Cambridge University Press, 1993. p.166-173.

VILLA NOVA, N.A.; BACCHI, O.O.S.; REICHARDT, K. Potencial de água no sistema solo-planta, estimado através da fase vapor. Scientia Agricola, Piracicaba, n. 1, v. 53, p. 194-198, 1996.

VILLA NOVA, N.A.; ANGELOCCI, L.R.; VALANCOGNE, C.; SENTELHAS, P.C.; PEREIRA, A.R.; MARIN, F.R. Estimativa da transpiração máxima de macieiras em pomares irrigados pelo método de Penman adaptado. Revista Brasileira de Agrometeorologia, Santa Maria, v.10, n.2, p. 245-250, 2002.

WEIBEL, F.P.; de VOS, J.A. Transpiration measurements in apple trees: an improved stem balance heat technique. Plant and Soil, Dordrecht, v.166, p.203-217, 1994.

WILlMOTT, C.J., ACKLESON, S.G., DAVIES, R.E., FEDDEMA, J.J., KLINK, K.M., LEGATES, D.R., O'DONNELL J., ROWE, C.M. Statistics for the evaluation and comparison of models. Journal of Geophysical Research, Washington, v.90, n.5, p.8995-9005, 1985. 